Mavi Atlas, 6(1)/2018: 326-348. Araştırma Makalesi | Research Article

Makale Geliş | Received: 11.02.2018

Makale Kabul | Accepted: 30.03.2018

DOI: $10.18795 /$ gumusmaviatlas.419008

M. Yasin TAŞKESENLİOĞLU

Dr. Öğr. Üyesi

Bayburt Üniversitesi, İnsan ve Toplum Bilimleri Fakültesi, Tarih Bölümü, Bayburt-Türkiye Bayburt University, Faculty of Humanities and Public, Department of History, Bayburt-Turkey

ytaskesen@bayburt.edu.tr

\title{
Siyaset ve Modernleşme Karşısında İlmiye Ricâli
}

\section{$\ddot{O} z$}

Bu çalışma, kalemiye (mülkiye) ve seyfiye (askeriye) sınıfı ile birlikte devletin en önemli sacayaklarından birini oluşturan ve aynı zamanda Şeyhülislâm'dan talebeye kadar çok geniş bir yelpazeyi kuşatan ilmiye sınıfının merkezdeki temsilcilerinin devlet/siyasi erk ile münasebetini konu almaktadır. Bilhassa bu sınıfın ricâl-i ilmiyye olarak adlandırılan, devletle doğrudan temas halindeki üst düzey mensuplarının siyaset karşısındaki vaziyetine yoğunlaşmaktadır. Diğer taraftan Lale Devri'nde başlayan modernleşme süreci, 19. yüzyılda her alanda yapılan ıslah çalışmaları ile birlikte büyük bir ivme kazanmıştır. Geleneksel devlet ve toplum yapısında önemli değişiklikler meydana gelen Osmanlı Devleti'nde reformcu devlet adamları, bu her iki alanda da Batı'dan etkilenme sonucunda modernleşmek için üstün bir çaba sarf etmiştir. Özellikle Batılı çağdaşlarının kanunlarını uyarlama yöntemi ile devletin yönetim mekanizmalarını düzenlemeye çalı̧̧an siyasi erk karşısında üst düzey ilmiye temsilcilerinin pozisyonu da ilmiye ricalinin devlet yönetiminde işgal ettiği yer açısından ve bu zümrenin bireysel tavırları bakımından değerlendirilmeye çalışılmıştır.

Anahtar Kelimeler: Osmanlı Devleti, Siyaset, Modernleşme, İlmiye Sınıfı.

\section{Ottoman Ulema Class Towards Politics and Modernisation}

\begin{abstract}
This study aims to narrate the relationship between the state, the political power of the day, and the central representatives of Ulema class including a wide range of people from Shaykh al-Islam to the disciples who constitute some of the most significant pillars of the state together with civil and military service. The study, more particularly, intends to focus on the political condition of high-ranking members of Ulema class, who have a direct contact with the state. On the other hand, it can be observed that the modernisation tendency beginning with Tulip period gained acceleration with the large-scale reformist arrangements in 19th century. Influenced from the Western principles, the reformist statesmen of Ottoman Empire in which significant changes happened in the traditional structure of the state and the society made a huge effort to be modernized. In this sense, the position of the high-ranking representatives of Ulema towards the governing power, who regulates the management mechanisms of the state by the way of adapting contemporary Western legislations, will be analysed in terms of Ulema's occupation in state governance and of the individual attitudes of this class.
\end{abstract}

Keywords: Ottoman Empire, Politics, Modernization, Ulema Class. 


\section{Giriş}

Osmanlı Devleti'nin teşekkül dönemlerinde devlet düzeninin dini referanslarından ötürü en etkili zümrelerden biri olan ilmiye sınıfı, esasen Kanuni dönemindeki düzenlemelere kadar kalemiye ve seyfiyeden ayrı değerlendirilebilmesi güç bir pozisyona sahipti. Klasik eğitim sisteminin temeli olan medreseler üzerinde bu zümrenin uzun dönemler devam eden tahakkümü, diğer teşkilat birimleri nezdinde ilmiye sınıfına merkezi, manevi bir konum kazandırmaktaydı. Taşrada kadının, merkezde ise kazaskerin şeriat dışında sosyal düzeni sağlamaya yönelik yetkileri ile ulemanın eğitim işlerini yürütmesi ilmiye sınıfının devlet mekanizmasında ne derece önemli bir yeri olduğunu göstermektedir. Ayrıca aynı dönemlerde ilmiye mensuplarının mevcut yönetim sistemini meşrulaştırma gayretleri de (Cihan 2004: 14) bu sınıfın siyasi erke entegre edilmiş olduklarını göstermekteydi. Buna rağmen Osmanlı devlet düzeninde en yüksek ilmiye makamı olan Şeyhülislâmlık -her ne kadar Padişahlar I. Selim'den itibaren Halife unvanını haiz idiyse de- dinin de en yetkin temsil makamıdı. Fakat şer'î ve örfî hukuka dayanan, hatta alışılagelmiş bir söylemi tekrar edecek olursak bir şeriat devleti hüviyeti taşıyan Osmanlı Devleti'nin klasik yönetim düzeninin simgesi olan Dîvân-1 Hümâyûn'da Şeyhülislâm bulunmuyordu. Şeyhülislâm, sadece görülen lüzum üzerine istisnaî bir durum olarak divana davet edilirdi (Uzunçarş11ı 1988: 178, 188). $\mathrm{Bu}$ durum, devlet yönetiminde dinin yerini tayin etmek açısından önemli bir emaredir. Bir görüşe göre bunun nedeni, Şeyhülislâm'ın divanda bulunmasıyla manevi otoritenin Veziriazam'ın hareket özgürlüğünü kısıtlayacağıydı ki bu yüzden Kazaskerlerin divan üyeliği yeterli görülmüştü (Mumcu 1986: 57). Şeyhülislâmlar, Padişah'ın iradesi ile veya Sadrazam'ın arzının Padişah tarafından kabul görmesiyle göreve gelirlerdi. Görevden alınmaları da Padişah’ın emri neticesinde gerçekleşirdi. 18. yüzyıldan itibaren azledilme kararları Reisülküttap aracılığı ile kendilerine bildirilen Şeyhülislâmların bir diğer azledilmiş Şeyhülislâm ile görüşmeleri Tanzimat'a kadarki süreçte yasaklanmıştı (Sakaoğlu 1985: 265). Bununla birlikte Şeyhülislâm teamülen yalnız Sadrazam değiştiğinde onu tebrik için Bâbıâli’ye gelirdi (Uzunçarşı11 1988: 187). Ancak kanunların Şeyhülislâm'ın onayıyla meşrulaşması yönetim açısından devletin 
İslâm hukukuna bağlılığını göstermekteydi. Bu yetki, son söz mahiyeti taşımamakla birlikte istişarî bir nitelikteydi. Her ne kadar Dîvân-1 Hümâyûn üyesi olmasa da Şeyhülislâm'ın ait olduğu ulema sınıfı, bu yönüyle Osmanlı idarî sisteminde ayrıcalıklı bir yere sahipti. Şeyhülislâmlık ile resmi hüviyet kazanarak en üst makamda temsil edilen ulema, devlet yönetiminde, Halil İnalcık'ın tabiriyle Padişah'a müşavirlik yapma görevini yürütmekteydi (İnalcık 2014: 232). Fakat Ebussuud, İbn Kemal ve Zenbilli Ali Efendiler zamanında bu makam, sahiplerinin kişiliği ve nüfuzundan ötürü güçlü bir görüntü çizdiğinden devlet yönetiminde nispeten daha fazla ağırlığını hissettirmişti. ${ }^{1}$

Mal ve mülklerinin müsadere edilmemesi ile vakıflar üzerindeki etkin pozisyonları bu sınıfı maddi olarak da diğer sınıflara üstün kılmaktaydı (Faroqhi 2006: 680). ${ }^{2}$ Devlet ricâlinin edindiği servetin müsadere edilebilmesi, siyasî nüfuz kurmayı engelleyen bir kontrol mekanizması şeklinde işlemekteydi. Müsaderenin ilmiye sınıfına uygulanmaması, siyasetten tecrit edilmesinin verdiği rahatlıktan, hatta devletin bekasını sarsmaya yönelik bir tehdit olarak görülmediğinden ötürüydü.

Seyfiye sınıfının en güçlü temsilcisi olan yeniçeriler de hesaba katıldığında 17. ve 18. yüzyıllara kadar Padişah, ulema ve yeniçeri arasında genel olarak bir uyum olmakla birlikte bu dönemlerden sonra çatışma alanları daha çok ön plana çıkmaktaydı (Tanör 1985: 10). Yeniçeriler ile ulemanın birlikte hareket ederek potansiyel bir muhalefet olduğu şeklinde yorumlanabilecek bu düşünceye karşın, Berkes’e göre yeniçeri ocağı, ulema ve şeriatçıların değil, aşağı kademede Bektaşilerin, yukarıda ise siyasî çıkarcıların elinde bir vasıtaydı (Berkes 2004: 78). Ancak tam tersine yeniçeriler de devlet yönetimine müdahalede bulunurken meşrulaştırma vasıtası olarak halk nazarında saygın bir yeri olan ulemanın desteğine ihtiyaç duymuştu (Gencer 2017: 169). Yani ulemanın İslâmî temsil gücü ile toplum nazarındaki itibarı hem mülkün temsilcisi olan

1 Zembilli Ali Efendi, Yavuz Sultan Selim'in emirlerine uymayarak ipek satın alan 400 kişinin öldürülmesi kararına karşı gelmişti. Sultan'ın “ Saltanat işleri senin görevin değildir” uyarısına karşın Şeyhülislâm, "Bu ahirete yönelik işlerdendir. Müdahalede bulunmak beni görevimdir" karşıllı̆ıını vermişti (Yakut 2014: 15).

${ }^{2}$ Cevdet Paşa'nın vezirlik rütbesi almadan önce İlmiye sınıfında kalmakta ısrar etmesinin sebebi de buydu Cevdet Paşa, 1-12/1991: 63.). İlber Ortaylı, Cevdet Paşa'nın ilmiye sınıfından vezirliğe geçişini Tanzimat dönemindeki reform hareketinin ilmiye sınıfını zayıflattığının bir örneği olarak değerlendirmektedir (Ortaylı 2008: 264). 
devletin (de-jure) bekası hem de devlet içindeki askeri kanadın müdahaleleri (de-facto) arasında bir rol oynamıştı. Dolayısıyla yeniçeriliğin kaldırılması, ulemanın devlet kontrolüne geçmesini hızlandırdığg gibi devlet içinde kalmasını da sağlamıştı.

Ubicini, 1850 yılında kaleme aldığı eserinde ulema hakkında şöyle bir soru sormaktadır: "Tanzimatın her hususta tatbik edildiği, adlî işler ve görevler ulemanın hem bir imtiyazı hem de bir tekeli olmaktan çıkarılıp diğer devlet hizmetleri içinde eritilerek hükümet tarafindan maaşları karşılanan kurumlar haline getirildikleri zaman kadıların gördükleri davalardan almakta oldukları şu büyük kazançlar ne olacaktır?" (Ubicini: 106-107). Ona göre ulemanın devlet düzenindeki mevcut pozisyonu, modernleşen devlet için bir problemdi. Tanzimat hareketinin adlî işleri ilmiye sınıfının tekelinden çıkarmak suretiyle onları maaşlı bir memur sınıfına dönüştürmesi, ulemanın gücünü kıracak ve böylece reformların kapısı aralanacaktı. Oysaki devletin medenileşememesinde kabahatli olan ulema -ki ona göre Tanzimat dönemindeki mücadele bütün reform teşebbüslerini üstlenen hükümet ile eskinin olduğu gibi kalmasını isteyen ulema arasında cereyan ediyordu- hareketin başına geçip reformlarda başat rol üstlenseydi kendi otoritesini daha rahat bir şekilde güvence altına almış olacaktı (Ubicini: 107,108). Bir başka benzer görüşe göre ise Osmanlı Batılılaşması boyunca ulema, bir zümre olarak muhalefette kalmıştı (Davison 2011: 680). ${ }^{3}$ Dolayısıyla bu düşünceler Tanzimat hareketini, reformcular kanadı ile muhalefetteki ulema zümresi arasında cereyan eden bir süreç olarak değerlendirmektedir. Oysaki ulema, sınıf itibariyle bir zümreyi ifade etmekte kullanılmakla birlikte muşahhaslaştırıldığı zaman muğlaklığı ve değişkenliği artan bir yapıya bürünmektedir. Şöyle ki bütün bir Tanzimat hareketi boyunca yeniliklerin içerisinde yer alan Cevdet Paşa, ilmiye sınıfından gelmekteydi. Yine Mustafa Reşid Paşa ile Ali ve Fuad Paşa dönemlerindeki Şeyhülislâmlardan Arif Hikmet Beyefendi ile halefi Meşrepzâde Arif Efendi, ${ }^{4}$ ulemayı temsilen yapılan tüm düzenlemelere destek vermiştir. Daha eski

\footnotetext{
${ }^{3}$ Davison'a göre ulemadan birinin batılı dil bilmemesi onun cahilliğine delaletti. Bkz. aynı yer. Müellif aynı görüşü kapsamlı bir eserinde de yansıtmıştır (Davison 2005: 23, 26, 45, 70 vd.).

${ }^{4}$ Erdem sahibi, bilgin bir idareci ve Bâbıâli tarafından çok beğenilen bir zat olarak tanınan Meşrepzâde Arif Efendi, sınıfının gereği üstlendiği görevlerin dışında Anadolu teftişi ve Meclis-i Vâlâ üyeliği (1846)
} 
dönemlere gidildiğinde modernleşmenin önemli merhalelerinden birini teşkil eden matbaanın kuruluş sürecinde, yaygın bir kanaate göre, ulema muhalefette kalmış ve bağnaz bir duruş sergilemiştir. İddiaya göre kitap basmanın şeriata aykırı olduğu gerekçe gösterilmişti. Fakat bu iddia, herhangi bir somut dayanak noktasından hareket edememiştir. Bilakis döneminin Şeyhülislâm'ı Abdullah Efendi, gerek duyulan fetvayı hemen vererek matbaanın kuruluş sürecini desteklemişti (Berkes 2004: 57). Ayrıca son yüzyıl içerisinde yapılan bütün reformlarda yahut oluşturulan bütün reform meclislerinde ulema az ya da çok temsil edilmiştir. ${ }^{5}$ Hatta bir görüşe göre ulema, yenilik projesini hazırlayan ve bu projeyi meşrulaştıran bir görüntü arzetmiştir (Şeker 2015: 89). Bununla birlikte ilmiye, 19. yüzyılın başlarında kalemiye ve seyfiye sınıflarıyla genel olarak uyumlu bir görüntü arzetmekteydi. Bunda Sultan III. Selim'in sslahat programının kuşatıcı olmasının payı vardı. Ayrıca ilmiye ricâlinin gündemini meşgul eden hususlardan biri de devletin aksayan yönlerini tespit etmekti. Nitekim III. Selim'e sunulup değerlendirilmeye alınan meşhur 18 sslahat layıhasından 5'i ulema tarafından yazılmıştı. Layıhalar arasında en önemlisi yine ulemadan Kazasker Abdullah Molla'ya aitti (Berkes 2004: 92). ${ }^{6}$ Fakat zamanla bu sınıfın yadsınamayacak derecede güç ve itibar kaybettiği, bilinen bir gerçektir. Özellikle bu yüzyılda toplumun ve devletin düşünce dinamiklerini eline almayı başaran yeni bir aydın tipinin oluşması, ulemanın itibar kaybını hızlandırmıştır. Zirâ bu yüzyılda ortaya çıkan münevver kavramı, entelektüel manada bu yüzyıla kadarki ulema kavramının yerine ikame edilen bir kavram haline dönüşmüştür. Bunun belli başlı saikleri vardır. Ulema arasında zâdegânlık veya beşik ulemalığı bu sınıfın güç kaybetmesinin kronik nedenlerinden biridir. Ayrıca modernleşme ile beraber aydın olma şartları arasında Batı dillerinden en az birini bilmek gerekmekteydi. Ancak ulema, genel anlamda bu nitelikten yoksun

gibi Tanzimat görevlerinde de bulunmuştur. Sırasıyla Anadolu ve Rumeli Kazaskerliği görevlerinin ardından 24 Mart 1854'te Şeyhülislâm olmuştur. Bu makamda 27 Aralık 1858 tarihinde vefatına kadar kalmıştır. Arif Efendi’nin hazırladığı Dede Cöngi'nin siyasetnamesinde, kendi tercüme- $i$ hâli de yer almıştır. Yukarıdaki bilgiler bu eserden derlenmiştir (Siyâset-i Şer iyye Tercümesi 1275: 2-6), (İpşirli 1991: 365; Şeref 1985: 243-244)

5 Ahmet Cihan, İmiye Sinıfı adlı eserinin neredeyse tamamında ulemanın Osmanlı devlet kademelerindeki temsil gücünü sayısal veriler ile ortaya koymuştur (Cihan, 2004)

${ }^{6}$ Niyazi Berkes'e göre Abdullah Molla'nın, ulemadan olduğu halde, askerlik konuları hakkındaki bilgisi şaşırtıcı derecede moderndi (Berkes 2004: 96). 
olunca değişen aydın zümre tanımlamasında yerini alamamıştır ki aydından kastedilen zümre bürokraside yetişenler ve Yeni Osmanlılar' dı. ${ }^{7}$ Nitekim Ahmed Cevdet Paşa, ulemanın hoş karşılamadığından ötürü Fransızca’yı gizli gizli öğrendiğini belirtmektedir (Cevdet Paşa 40/1991: 21). Ulemanın itibarlı pozisyonunu kaybetmesi ve Yeni Osmanlılar'ın Osmanlı aydınını temsil etmesi, İslâmı̂ muhalefetin de ilkinden ikincisine geçmesine neden olmuştu (Gencer 2017: 193, 208). ${ }^{8}$ Bunun yanı sıra devletin genel anlamda yönetici zümresi ve aydını için görüşü açıktı. Aydın, devlet içinde kalmalıydı ve gerektiğinde yeni görevler almak suretiyle mevcut düzenin devamlılığını sağlamalıydı. Entelektüel çizgiden sapan, batılılaşmanın ürettiği aydın tipine uymayan (veya dışarda bırakılan) ve devletin yönetim çemberinin içinde tutularak özgünlüğü eritilen Şeyhülislâm şahsındaki ulema zümresi, kaybettiği itibarını bir daha geri alamamıştı. Bunda ulemanın aydın ile Batı arasındaki organik ilişkiden tedirgin olup, toplum nazarındaki yerleşmiş itibarını koruma güdüsünün de etkili olduğu söylenebilir. Bilindiği gibi modernleşme Osmanlı toplumunda tavandan tabana bir eğilim gösterdiğinden reformist zümre halk nazarında gâvur yaftasına maruz kalabiliyordu. ${ }^{9}$ Özellikle reformlar yüzyılı olan 19. yüzyıl modernleşmesi incelenirken çift kutuplu bir şekilde reformcular ve gericiler olarak kodlanan zümreler, kendi dönemi içinde batıcılar ve muhafazakârlar şeklinde algılanıyordu. Bu ikilik arasında şeriatın temsilcisi olarak

7 Şerif Mardin bu görüştedir (Mardin 1985: 46-54). Niyazi Berkes konu hakkında şu ifadeleri kullanmaktadır: “...eskinin ulemâ ocağının yerini almak üzere olan "aydın” tipi, daha sonra değişecek olan modern intelligentsianın öncüleri olarak doğmak üzeredir.” (Berkes 2004: 101); İsmet Özel, bu tartışmaya şu düşüncelerle katılır: “...Batı'da aydınların ilk ceddi rahip ise Türkiye’de müftü ve müderris olması gerek. Böyle bir varsayımı kabule değer gördüğümüz durumda farklar hemen belirginleşiyor... Rahip siyasi otoriteden bağımsız ve sosyal hayat üzerinde etkili, söz sahibi kiliseye mensuptu; dolayısıyla devletle yarışmayı, halkın devletle olan ilişkilerine yön vermeyi mümkün kılan bir konuma sahipti. Müftü ve müderris ise Fatih devrinden bu yana birçok şair ve ediple birlikte Ulemâ-yı Rüsum içindeydi, yani Türk aydınının ceddi devletten para alan, devletin beslediği bir tabakadan başka bir şey değildi." (Özel 1985: 61) İlber Ortaylı ise ulemayı Tanzimat'ın yönetici ve yürütücü kadrosu içerisinde değerlendirmeyip Tanzimat adamı dediği tipte ulemaya yer vermemektedir (Ortaylı 2008, 261 vd.). Mehmet Kaplan'a göre Tanzimat'tan önce medreseden yetişen ulema ile tekkeden yetişen veli olmak üzere iki aydın tipi vardı. Ancak Tanzimat'tan sonra bu iki zümre aydın tipinin dışında kalmıştı (Kaplan 1994: 114).

${ }^{8}$ Bedri Gencer, aydının temsil zümresinin el değişmesini daha sistematik bir şekilde kavramlar üzerinden değerlendirir: "Modernleşen dünyada Osmanlı Devleti, grupsal olarak ulemânın düşüşüne üdebânın yükselişine zemin hazırlayan geri çevrilemez bir değişim sürecine girmişti; iktidar, artık entelektüel olarak üdebâ denen eski kalemiye, yeni mülkiyenindi." (Gencer 2017: 227). Müellif burada Yeni Osmanlılar'ı üdebâ kavramıla tanımlamaktadır.

${ }^{9}$ Berkes'in şu ifadeleri dikkat çekicidir. “...Din alanından çağdaşlaşma akımına katılanlar ancak ondan kopmakla bunu yapabilmişlerdir.” (Berkes 2004: 204). 
Şeyhülislâmlık makamı, konumunun belirlenmesinde zorlanılan bir sürece girmiş oluyordu. Özellikle Tanzimat Fermanı'ndan sonra gittikçe güçlenen bürokrasi karşısında ilmiye sınıfı iyice gözden düşmüştü ki devleti içine düştüğü durumdan kanun yapmak suretiyle kurtarmaya çalışan siyasi erk, bu görevi de ulema yerine bürokratlara vermişti (İnalcık 2011: 104).

\section{Kırılmalar}

Devletin modernleşme çabalarını şeriat ölçüsüne vurmak ${ }^{10}$ bu çalışmanın nihai amacı veya hedefi değildir. Burada üzerinde durulan başlıca unsur Padişah’a manevi otorite kazandıran Halifelik unvanı dışında fetva yetkisini elinde bulunduran ve görünürde en yüksek mertebede ve ulemanın başında bulunan Şeyhülislâm nezdinde ilmiye sınıfı ile devlet arasındaki kırılmaları tespit etmeye çalışmaktır. Bunu da Şeyhülislâm ve bazı ilmiye ricâlinin devlet ile temas ettiği anlardaki davranışsal kırılmalar ile idari yani yönetimsel manada kırılmalar olarak iki şekilde değerlendirmeye çalışacağız.

\section{Davranışsal Kırılmalar}

Davranışsal kırılmalar olarak tanımladığımız bu kısımda 17. yüzyıldan birkaç örnek vermeyi uygun görmekteyiz. Zira bu yüzyıldaki siyasi erk ile ulema arasındaki temas anları ilginç durumların ortaya çıkmasıyla neticelenmiştir. 17. yüzyılın tanınmış Şeyhülislâmları Karaçelebizâde Abdülaziz ve Behâyî Efendiler saraya nüfuz edebilecek kadar siyasi erk kazanmışlardı. Sultan İbrahim, kendisini tahttan indirenleri hainlikle suçlayarak "bu nasıl iştir, ben Pâdişah değil miyim" diye itiraz edince, ulemadan Abdülaziz Efendi, kendisine mukabelede bulunarak şer'i esasları çiğneyip eğlenceye daldığı için hal edildiğini söylemişti. Bununla birlikte Abdülaziz Efendi IV. Mehmed'in

\footnotetext{
${ }^{10}$ Osmanlı modernleşmesinde ortaya çıkan bir düşünceye göre devletin kurtuluşu aynı zamanda dinin de kurtuluşu demek olduğundan dine aykırı yönleri dahi olsa devleti kurtarmaya yönelik atılan adımlar meşrudurlar. Bahsedilen konu ile ilgili bkz. (Kara, 2016: 33-34 vd).
} 
tahta çıkmasıyla önce Rumeli Kazaskeri, ardından da Şeyhülislâm olmuştu (İnalcık 2014: 113-114). Görüldüğü gibi saraydaki siyasi mücadelelere bir şekilde iştirak eden ulema, bu kaotik ortamdan istifade edip doğru siyasi tercihler sayesinde Şeyhülislâmlık makamına kadar ulaşmayı başarabilmekteydi. Dolayısıyla devletin klasik yönetim anlayışının zafiyet gösterdiği dönemlerde çatışma ortamının tarafgirleri arasında ulema ve bu zümreyi en üst derecede temsil eden Şeyhülislâm da yerini almıştı. Behâyî Efendi, dönemi içerisinde belki de en marjinal eylemlere imza atmıştı. Yasa dışı yollarla İzmir Limanı'nda buğday ticareti yapılmasını önlemek maksadıyla İngiliz Elçisi'ni, teamüllere aykırı olarak huzuruna çağırmış, sorumlu tuttuğu konsolosun azledilmesini talep etmiş, ret cevabı alınca önce elçiyi yumruklayıp ardından da hapse attırmıştı. Yeniçeri ağalarının elçiyi hapisten çıkarma gayreti içerisine girmelerine karşı da "Onların umûr-i dînde müdâhaleleri nedir, niçün hadlerini bilmezler... şimdiden sonra bu şehirde icra-yi şer' nice mümkündür" şeklinde tepki vermişti (İnalc1k 2014: 114115). Şeyhülislâm, gösterdiği gerekçe ile şer’i esaslardan taviz vermediğini göstermiş olsa da devletin siyasî erkine doğrudan müdahalede bulunarak Sadrazam'ın ve Padişah'ın görev alanını işgal etmişti. Ayrıca peş peşe Şeyhülislâmlık yapan Abdülaziz ve Mehmed Behâyî Efendilerin yukarıdaki faaliyetlerinin dışında tahtın el değişmesindeki etkileri, saraydaki nüfuzlarının boyutlarını ortaya koymaktadır (İnalcık 2014: 116).

$\mathrm{Bu}$ yüzyılın en önemli devlet adamlarından Köprülü Mehmed Paşa'nın ölümünden sonra ise Şeyhülislâm Mehmed Efendi, Padişah'ın huzurundayken Paşa'nın ölümünün iyi olduğunu, zira haksız yere çok kan döktüğünü söyleyince Köprülü'nün oğlu Fazıl Ahmed Paşa, "Her kimi katletti ise cümle senin fetvanla katletmiştir" diye cevap vermiş, bunun üzerine Şeyhülislâm, "Şerrinden korkardım, onun için fetva verdim" diyerek kendini savunmuş, Fazıl Ahmed Paşa ise bu cevap karşısında “Allah'tan korkmayıp mahlûktan korkmak ilm u diyanete lâyık mıdır?" sözleriyle tartışmayı noktalamıştı. Burada Şeyhülislâm'ın siyasî erk karşısındaki vaziyeti gayet açık bir şekilde ortadadır. Bununla birlikte klasik çağda Şeyhülislâmların nüfuz edebilmek için çeşitli yollara tevessül ettiği görülmektedir. Örneğin II. Mustafa'nın 
meşhur Şeyhülislâmı olan Feyzullah Efendi'nin yakınlarını yüksek dereceli müderrislikler ile kadılık görevlerine getirdiği bilinmektedir. Ayrıca Osmanlı tarihinde istisnaî bir durum olarak mahdumu Fethullah Efendi'nin Şeyhülislâm payesi almasını da Padişah nezdindeki nüfuzundan istifade yoluyla sağlamıştı ki bu nüfuz sayesinde devlet işlerine karışması kendi sonunu hazırlayıcı bir sebep teşkil etmişti (Uzunçarşılı 1988: 225). Bu yüzden yine istisnaî bir durum olarak Feyzullah Efendi'nin edindiği servetin büyük bir kısmı müsâdere edilmişti (Faroqhi 2016: 682). Feyzullah Efendi'nin bu girişimleri Şeyhülislâmlık makamının devlet düzenindeki ruhanî yerini sarsıcı adımlar olmuştu.

Şeyhülislâm nezdinde ilmiye sınıfının siyasî manada en etkin olduğu dönemin Meşveret Meclisleri dönemlerinde, özellikle I. Abdülhamid, III. Selim ve II. Mahmud dönemlerinde olduğu görülmektedir (Cihan 2004: 17). Dönemden döneme farklılıklar arzetmekle birlikte meşveret meclislerinde ilmiye mensuplarının ve Şeyhülislâm'ın ne derece etkili olduklarına dair bazı tespitler yapmak mümkündür. Herkesin fikrini açıçca ve çekinmeden ifade edebileceği düsturuyla hareket edilen bu meclislerde, ilmiye sınıfının siyasî ve askerî konulardan uzak durmaya çalıştı̆̆ı dönemler olmuştur. Örneğin 18 Aralık 1783 tarihinde Kırım'ın Çarlık Rusya tarafından ilhakını konu alan geniş katılımlı bir meclis toplanmıştı. Hâzırûna Kırım’ın ilhakı onaylanacak mı yoksa Çarlık Rusya'ya savaş mı açılacak? diye bir soru yöneltilmiş ve net cevaplar verilmesi beklenmişti. Eski İstanbul Kadısı Müftüzade Ahmed Efendi, Sadrazam'ın dahi tepkisini çeken bir cevap vermişti: "Bizler emirülmüminin olan padişahımızın rey ve emrine zahiren ve batınen muti ve munkadız. Bu madde niçin böyle oldu, diye bizlerden tariz vukuu mümkün değildir" şeklinde bir girizgâh yapan eski Kadı, akabinde Sadrazam'a dönüp “Siz Padişahımızın vekili mutlakısınız, bu babda re'y-i padişahi ne ise buyurun, biz de onи tasdik ederiz" diyerek sözünü tamamlamıştı (Cihan 2004: 68). Ahmed Efendi'nin siyasi erke tabiiyeti, Sadrazam tarafından şiddetle reddedildiyse de zamanla bu dönüşümün gerçekleştiği görülecektir. Diğer taraftan ilmiye mensuplarının Meşveret Meclisleri'nde dahi tam bir güven verilmediği sürece fikir beyan etmeye pek yanaşmadıkları anlaşılmaktadır (Cihan 2004: 73-76). 
19. yüzyılda siyasi erk ile dini otoritenin temas ettiği bir başka Kırım meselesi daha gündeme gelmişti. Kırım Harbi henüz patlak vermeden, durum tespiti yapmak ve olası bir savaşı değerlendirmek üzere toplanan mecliste savaş taraftarları ile karşıtları arasında kalan Şeyhülislâm Arif Hikmet Beyefendi ikircikli bir tavır takınmış ve onun bu tutumu Reşid Paşa'yı gücendirmişti (Cevdet Paşa 40/1991: 65). Kırım Harbi'nin gündemde olduğu bu hassas dönemde softalardan bazılarının eylem yapmalarına -ki Cevdet Paşa'ya göre softaları ayaklandıran Reşid Paşa'nın muhalifi Damat Mehmet Ali Paşa idi- Arif Hikmet Beyefendi'nin kayıtsız kalması da eklenince kendisinin makamda kalması iyice zora girmişti (Cevdet Paşa 40/1991: 66). Paşa'dan yana davranmaması, siyasî çekişmelerden zaten bunalan Şeyhülislâm'ın görevini bırakması ile sonuçlanmıştı.

Arif Hikmet Beyefendi'nin istifa sürecini burada örnek olarak göstermek meseleyi açıklayıcı bir yol olacaktır. Aydın'a göre onun münzevi bir hayat yaşamasının nedeni kendi ilkeleri ile Sadrazam Reşid Paşa'nın istekleri arasında sıkışıp kalmasından (Aydın 2013: 10) kaynaklanmıştı. İstifayla da yetinmeyen sabık Şeyhülislâm, ${ }^{11}$ kendi yolundan gidenlere son derece düşündürücü öğeler içeren bir de ögüt bırakmıştı. "Olur olmaz işe karışma deyu / nush u pend eylemişdi eslâfım / câh-ı fetva karıştırıp cebren / şûrişe düşdü cümle evsâfım / mümkin ise sülük-i râh-ı halâs / girmesin bu tarîka ahlâfim (Aydın 2013: 11; Kemikli, 2011: 34). ${ }^{12}$ Ayrıca söz konusu meclis oturumu, Sadrazam Reşid Paşa'yı koltuğundan etmekle birlikte mecliste Paşa'dan yana tavır koyan ve savaşı destekleyen Meşrepzâde Arif Efendiye de Şeyhülislâmlık yolunu açmıştı (Cevdet Paşa 40/1991: 66-67). Arif Hikmet Beyefendi, 19. yüzyıl yenileşme kurumlarının birçoğunda yer almasına rağmen Şeyhülislâmlığı döneminde dahi siyasî entrikalardan bunalmış ve gûşe-i tayyibe olarak adlandırdığı Medine'de inzivaya çekilmeyi bir

\footnotetext{
11 Ziya Paşa'ya göre Mısır Valisi Mehmet Ali Paşa'dan sonra vali olan oğlu İsmail Paşa'nın valiliğin babadan oğula veraset şekliyle geçmesini talep etmesi üzerine Reşid Paşa ile düştüğü fikir ayrılığından ötürü Arif Hikmet Bey istifa etmiştir (Kemikli 2011: 32).

${ }^{12}$ Devlet ricali arasındaki siyasî rekabet Tanzimat'ın her sürecine bilfiil dâhil olmuş ve aktif rol üstlenmiş olan Cevdet Paşa'yı dahi mustarip etmiştir. Paşa, rahatsızlı̆̆ını şu beyitle dile getirmiştir. Yârın vefâsı yok dil-i agyâr kîne-cû / Cevdet azîmet etmeli uzlet diyarına. (Cevdet Paşa,40/1991: 62).
} 
kurtuluş yolu olarak görmüştü (Kemikli 2011: 18). ${ }^{13} 1858$ yılında vefatına kadar Şeyhülislâmlık yapan Meşrepzâde, selefi Arif Hikmet Beyefendi'nin öğüdünün ironik bir şekilde muhatabı olmuştur. Şeyhülislâmlığı döneminden aktarılan bir anekdot yukarıdaki şiirin adeta bir tezahürüydü. Meclis-i Vükelâ'da görüşülen bir konu hakkında üyelerden birinin Arif Efendi'nin onayını alma gereğini dile getirmesi karşısında Meşrepzâde; "efendim her şeyi bize sormayınız, sormadan yaptığınız şeylere karışıyor muyuz, bizim bir ölçümüz vardır, sorulan şeyleri o ölçüye vururuz, uyarsa ne âlâ, ya uymazsa..." (Abdurrahman Şeref 1985: 244) şeklinde cevap vermişti. Bu sözler, Arif Hikmet Beyefendi'nin şiirinin ilk mısraındaki seleflerin olur olmaz işe karışma nasihatinin Meşrepzâde tarafından tatbikinden başka bir şey değildi. Seleflerinin düştüğü bu durum, devletin son döneminde Şeyhülislâmlık makamının itibarını tamamen yitirmesi ile sonuçlanmıştı ki İttihat Terakki, istenilen fetvayı vermeyen Şeyhülislâm Mehmed Cemaleddin Efendi'yi sürgüne gönderecek kadar (Sakaoğlu 1985: 270) ileri gidebilecekti.

Meşrepzâde döneminde Şeyhülislâmlık makamının önceki dönemlere nispeten daha politize edildiği müşahede edilmektedir. ${ }^{14}$ Zira Kırım Harbi gibi nazik bir dönemde Fransa Elçisi'nin Meşrepzâde'nin yalısında kendisi ile görüşmesi (Cevdet Paşa 1-12/1991: 53-54) bu makam için teamüllere aykırı bir durumdu. Kırım Harbi esnasında Arabistan bölgesinde meydana gelen isyan ve bu isyana karşı Meşrepzâde'nin takındığı tavır dikkate değer bir olaydır. Mekke Emiri Abdülmuttalib Efendi'nin İngiltere ve Fransa gibi Hristiyan devletlerle Osmanlı Devleti'nin ittifak kurmasını gerekçe göstererek isyan etmesiyle gelişen olaylar üzerine, özellikle Osmanlı Devleti'nin Kırım Harbi'nde gayrimüslim devletlerden yardım almasının Mekke Emiri tarafından propaganda aracı olarak kullanılması karşısında Şeyhülislâm Arif Efendi

\footnotetext{
${ }^{13}$ Arif Hikmet Beyefendi'nin ilk idari görevi 1829 yılında Rumeli'de nüfus tahrir memurluğu yapmak olmuştur. Meclis-i Vâlâ üyeliği, Dâr-1 Şûrâ-y1 Askerî, Meclis-i Muvakkat, Meclis-i Maârif, Encümen-i Dâniş üyelikleri diğer görevlerinden bazılarıdır (Kemikli 2011: 21, 27).

${ }^{14}$ Bedri Gencer'e göre Arif Efendi, Tanzimat döneminin liberal şeyhülislâmı idi (Gencer 2017: 225). Buna mukabil Arif Efendi'nin siyasete yüklediği mana, onun bir ilmiyeli olarak siyaset içinde bulunmasını tarif eder niteliktedir. Zira Arif Efendi’ye göre siyaset insanların dünya ve ahiretini kurtarmaya sevk eden bir araçtır (Siyâset-i Şer 'iyye Tercümesi h.1275: 4).
} 
Mekke Kadısı ve ulemasına, onları teskin ve ikna amacıyla, bir mektup göndermişti. ${ }^{15}$ Kırım Harbi'nde bir Hristiyan devlete (Çarlık Rusya) karşı diğer Hristiyan devletlerle ittifak yapılması Şeyhülislâm'ın mektupta açıkladığı hususların başında gelmektedir. Kur’an-1 Kerim’deki “Ey iman edenler, kendinizden başkasını dost ve sırdaş etmeyiniz. Onlar size zarar vermekte kusur etmezler" ayeti ile Hz. Peygamber'in "Biz bir müşrikten yardım istemeyiz" hadisini değerlendiren Şeyhülislâm, Osmanlı Devleti'nin bu düsturdan dışarı çıkmadığını, ancak yardıma ihtiyaç olduğu ve uygun şartlar oluştuğu takdirde yardım almanın da caiz olduğunu savunmuştu. Meşrepzâde, Osmanlı Devleti'nin Kırım Harbi'nde bu devletlerden yardım almasını Hz. Peygamber'in iki Yahudi kabilesi olan Beni Kureyza’ya karşı Beni Kaynaka kabilesinden ve Huneyn Savaşı'nda bir müşrik olan Safvan bin Ümeyye'den yardım almasını emsal göstererek meşrulaştırmaya çalışmıştı. Sultan Abdülmecid'in Fransa ve İngiltere'nin yardım teklifini kabul etmeden önce ulema ve fakihlerin onayını aldığını da özellikle vurgulamıştı. Ayrıca savaşın sonunda ilan edilen Islahat Fermanı'nı hazırlayan komisyonda Arif Efendi de vardı. Gayrimüslimlere verilen haklar konusunda ciddi tartışmalara yol açan böyle bir metnin hazırlanmasında ilmiye sınıfının en üst derecedeki temsilcisinin yer alması, kurumun politize edilmesi ile birlikte yeni düzende yerini aldığına bir delil olarak gösterilebilir. Devletin önemli kararları alırken ilmiye sınıfını da dâhil etmesinin bir meşrulaştırma yolu olduğuna daha önce değinilmişti. Bununla birlikte bu fermanın hazırlanmasında Şeyhülislâm'ın bulunması halkın ve birtakım devlet ricâlinin dahi tepkisiyle karşılanmıştı ki en başta Reşid Paşa fermanda gayrimüslimlere verilen hakları eleştirmişti. Eleştiri noktalarından birisi gayrimüslimlerin yüksek görevlere gelmesinin önünün açılmasıydı. Meşrepzâde’ye göre bu fermanın hazırlanmasında Fransa ve İngiliz donanmalarının İstanbul'da demirlemiş olmalarının önemli derecede etkisi vardı. Ayrıca fermanın içeriği görüşülürken Gayrimüslimlerin devlet kademelerinde üst mevkilere getirilmesi hakkında meclisten açıklama isteyen Arif Efendi, tatmin edici bir cevap alamamıştı. Olaylara müşahitlik yapan Ahmed Vefik Paşa'ya göre Şeyhülislâm bu tavrını devam ettirdiği takdirde

\footnotetext{
${ }^{15}$ Bu mektubu Cevdet Paşa Tezâkir adlı eserinde neşretmiştir (Cevdet Paşa 1-12/1991: 133-138).
} 
azledilme ile cezalandırılabilirdi (Cevdet Paşa 1-12/1991: 73). Nitekim siyasi konjonktüre boyun eğen Şeyhülislâm'ın ferman hakkındaki çekinceleri ve itirazı sonuçsuz bir girişim olmaktan öteye geçememişti. Şeyhülislâm'ın bu iki olaydaki yaklaşımını dini yönden, ittifak kararını da siyasi yönden irdelemek maksadını taşımamaktayız. Fakat burada konu edilen Şeyhülislâm'ın düşünceleri ile bu bilgiler örtüştürüldügünde farklı bir durum ortaya çıkmaktadır. Nitekim İngiltere ve Fransa gibi devletlerle ittifak kurmayı meşrulaştıran Şeyhülislâm, Gayrimüslimlere Islahat Fermanı'nda haklar verilirken mevcut konjonktürü yani Fransa ve İngiltere gemilerinin İstanbul'a demirlemiş olduklarını (ki bu devletlerin donanmalarını İstanbul'a göndermeleri onlarla yapılan ittifakın ürünüydü) gerekçe göstermişti.

Bir başka çarpıcı olaydan da burada bahsetmek gerekmektedir. İlmiyeden Sadık Efendi'nin camide mevcut yönetime karşı siyasi eleştiriler yapması dönemin Şeyhülislâmı Hasan Fehmi Efendi (1874-1876) tarafından uyarılmasına neden olmuştu. Şeyhülislâm'ın kendisine ve vükelaya dair eleştiriler yapmaması için haber gönderdiği Sadık Efendi eleştirilerine devam etmesi üzerine görevinden azledilerek hapsedilmişti. İlmiye sınıfından gelen itirazlar üzerine serbest kaldıktan sonra hapsedilmesinin müsebbibi olarak Şeyhülislâm'1 gösteren Sadık Efendi’ye Şeyhülislâm “Şimdiki Şeyhülislâmlık resmidir. Benden bir şey sual ettikleri yok...” (Yakut 2014: 101) cevabını vermişti.

Tanzimat döneminde ilmiye ricâlinin siyasî erk karşısında direnç gösterdiği dönemler de vakidir. Bunlardan birisi, Ticaret Kanunu hazırlanırken yaşanmıştı. Fransa örnek alınarak hazırlanan Ticaret Kanunu'nu görüşme aşamasında bu kanunun dinî yönden uygunluğu meselesi gündeme geldiği esnada Reşid Paşa, "Şeriatın bu konuda yapacak bir şeyi yoktur" cevabını vermişti. Meclis-i Vâlâ'da meydana gelen bu olayda hazır bulunan ulemanın tepkisi Reşid Paşa’yı Sadrazamlıktan etmeye kadar gitmişti. Ancak bir süre ertelenen kanun, ilerleyen yıllarda onaylanacaktı (Yakut 2014: 108). Mecelle hazırlanırken de benzer bir olay meydana gelmişti. Eski ilmiyeli Cevdet Paşa öncülüğünde oluşturulan komisyona karşı çıkan Şeyhülislâm Hasan Fehmi Efendi, bu işin kendi makamına ait olduğunu iddia ederek, komisyon başkanlığından Cevdet Paşa 
alınmış ve komisyon çalışmaları Şeyhülislâmlığa devredilmişti. Fakat burada hazırlanan kısımlar da uygun bulunmayarak yeniden eski vaziyete geri dönülmüştür (Cevdet Paşa 40/1991: 96-97). Görüldüğü gibi dönemin gelişmeleri ve olayları esnasında Şeyhülislâm'ın öncülüğündeki ilmiye ricâli davranışsal olarak siyasi erke tabi olduğu sürece konumunu muhafaza edebilmiş, çatışmaların yaşanması ise genellikle bu sınıfın itibar kaybına neden olmuştur. İlmiye ricâlinin siyaset ve modernleşme karşısında takındığı tutum aşağıda görüleceği üzere birtakım yönetimsel kırılmaların da zeminini hazırlamıştır.

\section{Yönetimsel Kırılmalar}

Dîvân-1 Hümâyûn döneminde bu kurulun üyesi olmayan Şeyhülislâm, modernleşme döneminde divanın yerini alan en üst düzey meclis olan Meclis-i Vükelâ'da yerini almıştı. Bir nevi bakanlar kurulu görevini ifa eden bu mecliste Şeyhülislâm da şeriatı temsilen bulunuyordu. Ayrıca 19. yüzyıldaki meclisleşme süreci devletin diğer idari mekanizmalarında olduğu gibi Şeyhülislâmlık ve bağlı birimlerinde de kendini göstermişti (Yurdakul 2017: 232). Bu meclisler Şeyhülislâmlığın birer alt birimleri olarak görev yapmış ve kurumun modernleşmesine katkı sağlamıştı. Şeyhülislâm'ın Meclis-i Vükelâ ve Meclis-i Âlî gibi yüksek dereceli Tanzimat meclislerine üye olması, bu makamın manevi gücünün dışında devlet içindeki yerini tayin eden gelişmelerden biridir. Meclislerin çalışma yapısına göre, gündeme alınan konu müzakere edilirken her üye eşit haklara sahip olduğundan verilen kararda da üyelerin oyları birbirine denkti. Çoğunluğun oyu ne yönde olursa karar ona göre şekilleniyordu. Dolayısıyla Şeyhülislâm, meclislerde bir oy hakkına sahip olan ve diğer üyeler ile eşit bir pozisyona sahipti. Böylece bir konu hakkındaki mecliste yapılan oylamada çoğunluğun sağlanması karşısında aksi yönde görüş bildirse dahi Şeyhülislâm'ın bu karara uyması zorunluluğu doğmaktaydı. Ayrıca dönemin reform meclisleri olan Meclis-i Vâlâ ve Meclis-i Tanzîmât gibi meclislerde ulema müftî seviyesinde temsil edilmişti. Bunun amacı ise yapılan düzenlemelerin şeriata uygunluğunun sağlanmasıydı. Meclis-i Vükelâ ile birlikte çalışan bu meclislerden çıkan 
kararların Meclis-i Vükelâ'da görüşülmesi esnasında da Şeyhülislâm'ın bu meclise üye olması ulema arasında bir hiyerarşi ve sistem olduğunu göstermekteydi. Yani diğer meclislerdeki müftînin en üst meclisteki hiyerarşik temsilcisi Şeyhülislâm'd1.

Sultan Abdülmecid, Tanzimat Fermanı'nda öngörülen düzenlemelere dair tavrını net bir şekilde ortaya koymuştu. Fermanın gereklerini yerine getireceğine yemin eden Padişah, aynı yemini vükelâ ile birlikte ulemanın da vereceğini taahhüt etmişti. ${ }^{16} \mathrm{Bu}$, ulemanın Tanzimat hareketi karşısındaki tavrında bağlayıcı bir unsur olarak atılan en önemli adımdı.

19. yüzyılın siyasî düzeni içerisinde kalemiyenin en yüksek mercii olan Sadrazamlık makamını işgal edenler için ilmiye ricâlinin kudreti bir tehdit olarak algılanmaktaydı. Bu nedenle ulema arasında düzene daha çabuk adapte olan yeni bir tip ortaya çıktı (Cihan 2004: 271). Mesela devleti Batılı tarzda modernize etmeye çalışan II. Mahmud, yaptığı yeniliklerde döneminin Şeyhülislâmlarından büyük bir destek görmüştü (Bozkurt 2010: 46). Diğer taraftan şer'i esasların ihlalini önlemekle mükellef olan ilmiye ricâli Tanzimat döneminde, paradoksal bir şekilde, Padişah ve devlet adamları tarafından şer'i esaslara ve kanunlara uymaları için fermanlar, emirnameler ve ihtarlar çıkarılarak tekdir edilmişti (Cihan 2004: 271-272). Bununla birlikte teşrifatta Padişah resmi törenlerde sadece Şeyhülislâm karşısında ayağa kalkıp hatta diğer devlet görevlileri gibi el-etek öpmek yerine Padişah'ın yakasını ve omuzlarını öper iken, 1836 yılında yapılan teşrifattaki düzenlemeler ile Sadrazam ve Serasker ile aynı düzeye getirilmişti (Yakut 2014: 15). Bu durum ilginç bir şekilde sınıfın itibarını silikleştirmekle beraber siyasi erkin Osmanlı bürolarından yetişen yeni bir grup tarafından daha rahat kullanılmasını sağladı.

16 “... iş bu kavânîn-i şer 'iyye mücerred din ve devlet ve milleti ihyâ için vaz' olunacak olduğundan cânib-i hümâyûnumuzdan hilâfına hareket vuku' bulmayacağına ahd ü misak olunup hırka-i şerîfe odasında cemi' ulemâ ve vükelâ dâhil tahlif olunacağından ânâ göre ulemâ ve vüzeradan ve'l-hâsıl her kim olur ise olsun kavânîn-i şer'îyeye muhâlif hareket eden-lerin kabahat-i sâbitelerine göre tedîbât-l lâyıklarının hiç rütbeye ve hâtır ve gönüle bakılmayarak icrâsı zımnında mahsusen cezâ kanûn-nâmesi dahî tanzim etdirilsin..." Çeviri metin için bkz. (Tanzimat, Değişim Sürecinde Osmanlı Imparatorluğu, 2006: 15). Metinde değişim süreci için kullanılan ve sadık kalınması için cezai yaptırımdan bahsedilerek üzerine yemin ettirilen kavram kavân̂̂n-i şer'iye yani dini kanunlar idi. Ancak bu ifade ile kastedilen modernleşmeydi. Nitekim klasik döneminde olduğu gibi Tanzimat döneminde de kanunlar, dini esaslardan ziyade örfe ve gereksinimlere göre hazırlanmıştı. 
Osmanlı Devleti'nin klasik düzenindeki Dîvân-1 Hümâyûn'da yer almamakla birlikte özellikle 1slahatlar döneminde yaygınlaşan meşveret meclisinde Şeyhülislâmın bulunduğundan ve Meclis-i Vükela'da da Şeyhülislâmın üye olduğundan bahsedilmişti. Bununla birlikte ilmiye sınıfının temsilcileri diğer merkezî meclislerde de yer almakla birlikte bakanlar kurulu pozisyonundaki Meclis-i Vükelâ'da ilmiye sınıfını yalnızca Şeyhülislâm temsil etmekteydi. Ayrıca bir belgeden anlaşıldığı kadarıyla Şeyhülislâm, Meclis-i Vâlâ'ya atanacak üyeler hakkında tavsiyede bulunabiliyordu. Fakat bu, sadece tavsiye niteliği taşıyordu. Nitekim buna dair çıkan bir iradede Şeyhülislâm'ın tavsiye ettiği kişilerden bir kısmının Meclis-i Vâlâ'ya üyeliği münasip bulunmamıştı (BOA., I.DH., nr: 5/197). İlmiye sınıfının merkezî meclislerde yer almasının, henüz yasama, yargı ve yürütme erklerinin ayrışmamasından kaynaklandığı söylenebilir. Zamanla bu erkler ayrıştıkça ilmiye mensupları da daha çok yargı fonksiyonunu yürüten organlara kaydırılmıştır. Ancak merkezî yönetimde söz hakkı tanınan ulema, şer'i hususlarda varlığını hissettirmeye çalışmışsa da gerek devletin Batı kanunlarını resepsiyon yoluyla alma eğiliminde olması gerek de yabancı devlet temsilcilerinin siyasî baskısı sonucunda ulemanın etkinliği son derece sınırlı bir hal almıştı.

19. yüzyılda modern eğitim kurumlarının ihdas edilirken ulemanın konumu da yeni bir boyut kazanmıştı. Medresenin yanına alternatif bir eğitim kurumu olarak konulan mektep, seçkin ve aydın zümrenin öğrenim kurumu olarak tercih edilmiş, bunun sonucunda da ulema medreseye paralel olarak kan kaybetmeye ve silikleşmeye başlamıştı. Sanılanın aksine Lale Devri'nden III. Selim’e kadar yenileşme hareketinde aktör rolünde yer alan ulema, bu tarihlerden sonra daha dini sınırlar içerisine hapsolan/hapsedilen bir görüntü arzetmişti (Berkes 2004: 205). Ayrıca Yeniçeri Ocağı'nın kaldırılması devletin hızlı bir şekilde merkezîleşmesinin önünü açarken, Yeniçeri Ağası'nın eski konutu Şeyhülislâm'a devredilerek bu manevi otoritenin bürokrasinin bir uzvu olması yolunda ilk adım atılmış oldu (Lewis 2008: 136). Bâb-1 Meşihât adını alan bu yapı, Şeyhülislâm'ın çalışma ofisinin devlet tarafindan tahsis edilmesiyle ortaya çıkmıştı. Böylece ilmiye ricâlinin en üstündeki kişi, adeta bir devlet memuru haline dönüşmüş oldu. Böylece Saray’ın (dolayısıyla Padişah'ın) merkezî 
idarede monark yapısını tahdit, tahttaki varlığını da tehdit eden, yahut öyle görülen, ilmiye ve yeniçeri zümrelerinden birincisi pasivize, ikincisi ise ilga edilmiş oldu. Bundan sonraki süreçte Şeyhülislâm'ın fetvalarından siyasî mahiyeti en güçlü olan hal fetvası dahi eski bir uygulamanın devam ettirilmesinden başka bir mahiyet taşımayacaktı.

Meşrepzâde Arif Efendi'nin Şeyhülislâmlığı döneminde siyasî erk ve modernleşme ile son derece uyumlu bir yol takip edilmiş, onun döneminde (1854-1858) bütün yenilikler ve alınan kararlar onaylanmıştı (Abdurrahman Şeref 1985: 244). Nitekim vefatı dolayısıyla yerine gelen Mehmed Sadeddin Efendi'de bu uyum olmadığından, her kararı onaylamayıp itiraz ettiğinden dolayı Bâbıâlî’nin Arif Efendi’yi aradığı rivayet edilmektedir (Abdurrahman Şeref, 1985: 244). Bu dönemin en dikkat çekici reformlarından birisi kadılık kurumunda yapılmıştır. Muallimhâne-i Nüvvâb adıyla 1855 'te eğitime başlayan okulun gayesi mahkemelerdeki şer'i hâkim ihtiyacını karşılamakt1 (Feyzioğlu 2010: 64-66). Meşrepzâde'nin talebi doğrultusunda Süleymaniye civarında Mekteb-i Edebiye'nin binasında faaliyete başlayan bu okul (Feyzioğlu 2010: 65), Osmanlı devlet teşkilatında çok önemli bir yeri olan kadılığın geleneksel eğitim sürecine yeni bir boyut kazandırmıştı. Bu adım, ilmiye sınıfında düalizmin başlamasına sebep olsa da mekteplilik mefhûmunun bu sınıfta da yer almasını sağlayan başlıca amil olmuştu. Bu yenilik, Meşrepzâde'nin Reşid Paşa ekolünün ilmiye sınıfındaki temsilcisi olduğunu göstermek açısından önemlidir. Öyle ki bu okulda eğitim alanlar Tanzimat'ın modern yargı anlayışına uygun olarak oluşturulan mahkemelerde ve kurumlarda görev alabileceklerdi. Meşrepzâde döneminin bir diğer özelliği ise ilmiye sınıfını diğer alanlardaki düzenlemelere göre dizayn etmekti ki Şeyhülislâmlığının başlarında çıkarılan iki nizamname de yukarıda bahsedilen okulun ardıl gelişmeleri niteliğindedir. Bunlar aynı tarihte çıkarılan Tevcihât-ı Menâsıb-ı Kazâ Nizâmnâmesi (Düstûr, h.1289: 315-320) ile Nüvvâb Hakkında Nizâmnâme'dir (Düstûr h.1289: 321-324). 1855 yılında hazırlanan Tevcîhât-1 Menâsıb-1 Kazâ Nizâmnâmesi'ndeki esaslara uymayanların Tanzimat döneminde çıkarılan Ceza Kanunu'na göre yargılanması ve Eyalet Meclisleri'nin eyaletin naibinin 
uygunsuzluklarını inceleme yetkisini haiz olması (Feyzioğlu 2010: 75) ilmiyenin yeni düzende yerini alma ve diğer devlet kurumlarının Tanzimat anlayışına entegre olmak gayretiydi. Nitekim bunu mecbur kılan gelişmeler yaşanmıştı ki 1849 yılında kurulan Eyalet Meclislerine yargı hakkının verilmesi ve şer'i mahkemelerin gördüğü davaların bir kısmının bu meclislerde görülmeye başlanması Şeyhülislâmlığa bağlı kurumların yapılarında da güncelleme yapılmasını zarurî hale getirmişti.

\section{Değerlendirme}

Bilindiği üzere Reşid Paşa'nın oluşturduğu yeni aydın tipinden beklenen sadece Tanzimat hareketini özümsemesi değil, aynı zamanda Reşid Paşa'ya kayıtsız şartsız bağlılığıydı. Bu beklenti, reformların tek elden ve hızlıca gerçekleşmesi adına bir avantaj teşkil etmekle beraber teksesliliğin önünü açtığı için Osmanlı devlet geleneğindeki çoksesliliği de baltalıyordu. Reşid Paşa, Tanzimat'ın 1856 yılına kadarki sürecinde şüphesiz en etkin devlet adamı görünümündeydi. Paşa'nın tasavvur ettiği düşünceleri uygulamaya koyması için seçtiği yollardan biri, kendi düşüncelerini temsil eden kişiler yetiştirmekti. Özellikle bürolarda yetiştirdikleri sayesinde istediği devlet yapısını tesis etmek ve devamını sağlamayı hedeflemişti. Ali ve Fuad Paşaların dışında ulemadan ve kalemlerden yetiştirdiği veya hamilik ettikleri ile Tanzimat hareketini sorunsuz bir şekilde yürütmeye çalışmıştır ki Şinasi bunlardan biriydi (Kaplan 1994: 113). Paşa'nın bu siyaseti, bürokraside yeni bir patron tipi olarak değerlendirilebilir. Burada anakronik bir hata yapmaktan kaçınarak bir analiz yapmak, Reşid Paşa'nın yeni tip devlet adamı yetiştirme tercihini daha açıklayıcı bir hale getirecektir. Köprülüler adıyla maruf devrin başlangıcında Köprülü Mehmed Paşa, devlet düzenini yeniden tesis etmeye çalışırken, tasavvur ettiği düzenlemeleri sorunsuz bir şekilde gerçekleştirmek için kendi düşüncelerini temsil eden yönetici zümre yetiştirmek yerine mevcut durumda kendi düşüncelerine yakın kişileri göreve getirme yolunu seçmişti. Bir nevi kendi kadrolaşmasını daha kısa bir zaman diliminde ve daha pratik bir şekilde oluşturmaya çalışmıştı. Örneğin Sadrazam olduktan sonra, döneminin kargaşa ortamında siyasallaşmış olan iş birliği yapabileceği Molla Mustafa'yı Şeyhülislâmlık makamına 
getirtmişti (İnalcık 2015: 28). ${ }^{17} \mathrm{Bu}$, aynı zamanda Köprülü'nün Sadaret makamında kalmasını sağlayan, yani Şeyhülislâm'ın kendisini azlettirme fetvasını önleyen bir hamle olarak da yorumlanmaya müsaittir. ${ }^{18}$ Köprülü’nün yapmaya çalıştığı, Şeyhülislâm'ın elindeki fetva gücünü kullanarak siyasî faaliyetlerini önlemeye çalışmaktı. Bu düşünce Köprülüler devrinde kısmen başarıya ulaşmış olsa, uzun vadede Şeyhülislâm'ın saray üzerindeki manevi tesirinin siyasî boyutları devam etmişti. Mesela verdiği fetva ile Sultan III. Selim'in tahttan indirilmesinde rolü olan Şeyhülislâm, döneminin kargaşa ortamında Sadaret Vekili ile birlikte başkentte yönetimi elinde bulundurmayı başarmıştı (Lewis 2008: 100). Fakat Reşid Paşa, daha uzun vadede Tanzimatçı bir yönetici tipi oluşturmaya çalışmış, ileride yüksek göreve getireceği kişileri, Meclis-i Vâlâ gibi Tanzimat kurumlarında yetiştirerek onları tasavvur ettiği düzene adapte etmeye çalışmıştır. Diğer yüksek dereceli makamlara nispeten daha az el değiştiren Şeyhülislâmlık makamına oturabilmek için bazı ilmiye kademelerinden geçmek gerekirdi ki bunun son merhalesi Rumeli Kazaskerliği idi. Tanzimat hareketini başlatan Reşid Paşa döneminde bu teamülün biraz farklılaştı̆̆ı görülmektedir. Zira 1839'dan sonraki ilk Şeyhülislâm ataması 1846 yılında gerçekleşmişti. Tanzimat Fermanı'nın ilanı arifesinde Rumeli Kazaskerliği'nde bulunan Arif Hikmet Beyefendi, 1839 yılından 1846 yılına kadarki sürede Meclis-i Vala üyeliği, Tanzimat Müfettişliğgi, Dâr-1 Şûrâ-y1 Askerî üyeliği ve geçici Maarif Meclisi üyeliği görevlerini ifa etmişti. Böylece reformcu düşünce kendi aydın tipini oluştururken yönetici zümrenin Tanzimat hareketinde bizatihi yer almasını sağlıyordu. Arif Hikmet Beyefendi'nin 1840 yılında Tanzimat' 1 tatbik ve teftiş için Rumeli'ye müfettiş olarak gönderilmesi - ki ilmiye sınıfından olmakla beraber aynı zamanda Meclis-i Vâlâ üyesiydi- böylesi bir gayretin ürünüydü. Sultan Abdülmecid, Mekkizâde Asım Efendi'nin vefatı üzerine Şeyhülislâm olan Arif Hikmet Beyefendi'den böylesine nazik bir dönemde vükelâya önemli

${ }^{17}$ Köprülü Mehmed Paşa, Kaptan-1 Derya Seydi Ahmet Paşa'nın yandaşlarını alt etmek için Mustafa Efendi'ye bu güruhun faaliyetlerinin şeriata uymadığına dair bir belge imzalatmış ve Şeyhülislâm ile karşılıklı yemin etmişlerdir (İnalcık 2015: 29).

18 Zira bu dönemde Şeyhülislâm fetvaları, Yeniçeri Ocağı'nın da etkisiyle Padişah'ların tahttan indirilmesinde ve Sadrazamların azledilmesinde çok etkiliydi. Ancak Köprülü’nün azledilmesi yönündeki ocağın baskılarına karşı Şeyhülislâm Mustafa Efendi direnmiş ve azil fetvasını çıkarmamıştı (İnalcık 2015: 35). 
derecede yardım etmesini bekliyordu (Yurdakul 2017: 236). Zira Arif Hikmet Beyefendi'nin yenileşme karşısında hiçbir şekilde engelleyici bir tavır takınmadığ bilinmektedir. Aynı şekilde halefi ve adaşı Meşrepzâde Arif Efendi de Tanzimat'ın gereklerini icra eden heyetlerde görev alan bir ilmiyelidir. Tanzimat Fermanı'nın ilanından sonra reformların uygulanmasını denetlemek için Anadolu teftişi görevi ve 1846 yılındaki Meclis-i Vâlâ üyeliği bu cümledendir. Dolayısıyla bu zaman diliminde şöyle bir sonuç ortaya çıkmıştı ki devletin yönetim mekanizmasında ayrıcalıklı bir yeri olan ilmiye ricâli 19. yüzyılın ortalarına gelinceye kadar devletin dönüşümündeki safhalarda gelişen bürokrasinin bir uzvu şeklini almış, ricâl dışındaki ilmiye zümresi ise modernleşme ile birlikte yeni bir sınıf olarak ortaya çıkan aydın tipinin dışına itilmiştir. 


\section{KAYNAKÇA}

\section{Arşiv Belgeleri ve Resmi Zabıtlar}

Başbakanlık Osmanlı Arşivi (BOA), Irâdeler (I), Dâhiliye (DH), nr: 5/197.

Düstûr (h. 1289). I.Tertib, Cilt I, İstanbul.

\section{Kitaplar-Araştırma Eserleri}

Abdurrahman Şeref (1985). Tarih Musahabeleri, sad. Enver Koray, Ankara: Kültür ve Turizm Bakanlığı Yayınları.

AYDIN, Mahir (2013). Ahmet Arif Hikmet Beyefendi Bir Tanzimat Devri Şeyhülislâmı, Ankara: Türk Tarih Kurumu Yayınları.

BERKES, Niyazi (2004). Türkiye'de Çağdaşlaşma, 7. Baskı, hz. Ahmet Kuyaş, İstanbul: Yapı Kredi Yayınları.

BOZKURT, Gülnihâl (2010). Batı Hukukunun Türkiye'de Benimsenmesi, 2. Baskı, Ankara: Türk Tarih Kurumu Basımevi.

Cevdet Paşa (1991). Tezâkir 1-12, hz. Cavid Baysun, Ankara: Türk Tarih Kurumu Basimevi. Basımevi.

Cevdet Paşa (1991). Tezâkir 40, hz. Cavid Baysun, Ankara: Türk Tarih Kurumu Yayınları.

CïHAN, Ahmet (2004). Reform Çağında Osmanlı İlmiyye Sınıfi, İstanbul: Birey

ÇAĞMAN, Ergin (2010). III. Selim'e Sunulan Islahat Lâyihalart, İstanbul: Kitabevi Yayınları.

FEYZİOĞLU, Hamiyet Sezer (2010). Tanzimat Döneminde Kadılık Kurumu, İstanbul: Kitabevi Yayınları.

GENCER, Bedri (2017). İslâm'da Modernleşme (1839-1939), 4. Bask1, İstanbul: Doğu Batı Yayınları.

H. DAVISON, Roderic (2005). Osmanlı Imparatorluğu'nda Reform (18561876), 2. Baskı, çev. Osman Akınhay, İstanbul: Agora Yayınları.

İNALCIK, Halil (2014). Devlet-i 'Aliyye, Osmanl Imparatorluğu Üzerine Araştırmalar II, 1. Baskı, İstanbul: Türkiye İş Bankası Yayınları.

İNALCIK, Halil (2015). Devlet-i 'Aliyye, Osmanl İmparatorluğu Üzerine Araştırmalar III, 1. Baskı, İstanbul: Türkiye İş Bankası Yayınları.

KARA, İsmail (2016). Din ile Modernleşme Arasında-Çağdaş Türk Düşüncesinin Meseleleri, 5. Baskı, İstanbul: Dergâh Yayınları. 
KEMIKLİ, Bilal (2011). Şâir Şeyhülislâm Ârif Hikmet Beyefendi HayâtıEserleri-Şiirleri, İstanbul: Kitabevi Yayınları. Yayınları.

KÖKSAL, Asım Cüneyd (2006). Fıkıh ve Siyaset, 2. Baskı, İstanbul: Klasik

LEWIS, Bernard (2008). Modern Türkiye’nin Doğuşu, .çev. Boğaç Babür Turna, Ankara: Arkadaş Yayınları. Yayınları.

MUMCU, Ahmet (1986). Divan-ı Hümayun, 2. Bask1, Ankara: Birey ve Toplum

ORTAYLI, İlber (2008). İmparatorluğun En Uzun Yüzyılı, 26. Bask1, İstanbul: Timaş Yayınları.

Siyâset-i Şer'iyye Tercümesi (h.1275). çev. Mehmed Ârif Hikmet, İstanbul: Takvimhane-i Âmire.

ŞEKER, Fatih M. (2015). Modernleşme Devrinde Illmiye-Cevdet Paşa İbnülemin Örneği, 2. Baskı, İstanbul: Dergah Yayınları.

UBİCINİ, M.A. (Tarihsiz). Türkiye 1850, C.1, çev. Cemal Karaağaçlı, İstanbul: Tercüman Yayınları.

UZUNÇARŞILI, İsmail Hakkı (1988). Osmanlı Devletinin İlmiye Teşkilâtı, 3. Bask1, Ankara: Türk Tarih Kurumu Basımevi.

YAKUT, Esra (2014). Şeyhülislâmlık, Yenileşme Döneminde Devlet ve Din, 4. Baskı, İstanbul: Kitap Yayınları.

YURDAKUL, İlhami (2017). Osmanlı İlmiye Merkez Teşkilâtı'nda Reform (1826-1876), 2. Baskı, İstanbul: İletişim Yayınları.

\section{Ansiklopedi Maddeleri}

MARDIN, Şerif (1985). "Tanzimat ve Aydınlar", Tanzimat'tan Cumhuriyet'e Türkiye Ansiklopedisi, Cilt 1, ss. 46-54, İstanbul: İletişim Yayınları.

İPŞİRLİ, Mehmet (1991). “Ârif Efendi, Meşrepzâde”, Türkiye Diyanet Vakf (TDV) İslâm Ansiklopedisi, Cilt 3, 1991, ss. 365, İstanbul: Türkiye Diyanet Vakfi Yayınları.

ÖZEL, İsmet (1985). “Tanzimatın Getirdiği Aydın”, Tanzimat'tan Cumhuriyet'e Türkiye Ansiklopedisi, Cilt 1, ss. 61-66, İstanbul: İletişim Yayınları.

SAKAOĞLU, Necdet (1985). “19. yy’da Şeyhülislâmlık”, Tanzimat'tan Cumhuriyet'e Türkiye Ansiklopedisi, Cilt 1, ss. 263-270, İstanbul: İletişim Yayınları.

TANÖR, Bülent (1985). “Anayasal Gelişmelere Toplu Bir Bakış”, Tanzimat'tan Cumhuriyet'e Türkiye Ansiklopedisi, Cilt 1, ss. 10-26, İstanbul: İletişim Yayınları. 


\section{Makaleler-Yayımlanmış Bildiriler}

DAVISON, Roderic (2011). “Osmanlı Türkiye'sinde Batılı Eğitim”, çev. Mehmet Seyitdanlığlu, Tanzimat, ed. Halil İnalcık ve Mehmet Seyitdanlığlu, ss. 665681, İstanbul: Türkiye İş Bankası Yayınları.

FAROQHİ, Suraiya (2006). "Siyaset ve "Ekonomi Arasındaki Yönetici Seçkinler”, çev. Ayşe Berktay, Osmanlı Imparatorluğu'nun Ekonomik ve Sosyal Tarihi, Cilt 2, ed. Halil İnalcık ve Donald Quataert, ss. 543-757, İstanbul: Eren Yayınları.

İNALCIK, Halil (2011). "Sened-i İttifak ve Gülhane Hatt-1 Hümâyûnu", Tanzimat, ed. Halil İnalcık ve Mehmet Seyitdanlığlu, ss. 89-109, İstanbul: Türkiye İş Bankası Yayınları.

KAPLAN, Mehmet (1994). "Mustafa Reşid Paşa ve Yeni Aydın Tipi”, Mustafa Reşid Paşa ve Dönemi Semineri Ankara 13-14 Mart 1985, 2. Bask1, ss. 113-120, Ankara: Türk Tarih Kurumu Basımevi. 